\title{
First report of leaf spot disease on Woodfordia fruticosa caused by Corynespora cassiicola in Kerala, India
}

\author{
Sreelakshmi VP' ${ }^{1}$, Kumar $S^{1^{*}}$, Rekha $\mathbf{R}^{1}$, Nair $B^{1}$, George $\mathbf{N M}^{1}$ and Singh $\mathbf{R}^{2}$ \\ ${ }^{1}$ Forest Pathology Department, KSCSTE-Kerala Forest Research Institute, Peechi - 680653, Thrissur, Kerala, India \\ ${ }^{2}$ Centre of Advanced Study in Botany, Institute of Science, Banaras Hindu University, Varanasi - 221005, Uttar \\ Pradesh, India
}

Sreelakshmi VP, Kumar S, Rekha R, Nair B, George NM, Singh R 2021 - First report of leaf spot disease on Woodfordia fruticosa caused by Corynespora cassiicola in Kerala, India. Plant Pathology \& Quarantine 11(1), 9-14, Doi 10.5943/ppq/11/1/2

\begin{abstract}
Woodfordia fruticosa (L.) Kurz (Lythraceae), a significant medicinal plant used for curing various diseases, was severely affected with leaf spot disease in medicinal plants garden of Kerala Forest Research Institute, Peechi. Based on morphological characteristics the pathogen was identified as Corynespora cassiicola (Burk. \& Curt.) C.T. Wei. To the best of our knowledge this is the first report of leaf spot disease caused by C. cassiicola on W. fruticosa in Kerala, India.
\end{abstract}

Key words - Fungal diseases - identification - new report - pathogenicity

\section{Introduction}

Woodfordia fruticosa (L.) Kurz is one of the high demanding medicinal plants in the traditional and modern medicines that belongs to Lythraceae, commonly called Thamarapushpi, Thathiri (in Malayalam) and Dhataki Kusuma (in Hindi). The plant comes under IUCN 2.3 (least concern) category. The plant is used externally to relive the burning sensation of skin, flower are sprinkled overwound and ulcer for quick healing, and stop discharge of pus and granulation. According to the Indian Systems of Medicine, this flower is pungent, acrid, cooling, toxic, alexiteric, uterine sedative, anthelmintic, and used in thirst, dysentery, leprosy, erysipelas, blood diseases, leucorrhoea, menorrhagia and toothache. It is considered as 'Kapha' (mucilage type body secretion) and 'Pitta' (energy-dependent metabolic activity) suppressant in the Ayurvedic concepts of medicine (Sharma 1956). Many marketed drugs comprise flowers, fruits, leaves and buds mixed with pedicels and thinner twigs of the plant (Dutt 1922, Nadkarni 1954, Chopra et al. 1956, Ahuja 1965). The leaves of W. fruticosa are also used as a folk medicine in India and Nepal. In case of fever, decoction of Dawai (a popular name of this plant in this region) leaves in combination with sugar and dried ginger is recommended (Oudhia 2003).

In 2018, the plant was found infected with leaf spot disease in medicinal plants garden of Kerala Forest Research Institute, Peechi was collected for symptomatology and identification.

\section{Materials \& Methods}

\section{Sample collection}


The severely affected disease samples were collected from KFRI Medicinal Plants Garden, Peechi $\left(10^{\circ} 31^{\prime} 48^{\prime \prime N} 76^{\circ} 20^{\prime} 50^{\prime \prime E}\right)$. The digital photographs of the host plant, the symptoms on infected leaves and healthy leaves were taken at the time of collection using Sony Cybershot (DSCW810/B) digital camera. The host plant identity was confirmed by Digital CD of flowering plants of Kerala (Sasidharan 2012) and the taxonomy, verification and nomenclature of plant families, genera and species were done based on The Plants of the world online (http://www.plantsoftheworldonline.org/), and The Plant List (http://www.theplantlist.org). Fungarium was also prepared for infected sample as per standard techniques (Hawksworth 1974, Castañeda-Ruiz 2005) and kept in paper envelops along with collection details and deposited in recognized herbarium Ajrekar Mycological Herbarium (AMH 10053), ARI, Pune and duplicate of the same has been kept in KFRI Mycological Herbarium for future reference.

\section{Isolation and culturing of mycopathogen}

The collected infected samples were kept in a zip-lock polythene bag and brought to the laboratory for further detail study. Infection spots were primarily observed under a stereomicroscope to study the enlarge view of symptoms. The diseased leaf samples were washed in running tap water thoroughly to remove any dirt and were then surface disinfected with $0.2 \%$ sodium hypochlorite $(\mathrm{NaOCl})$ for 2 minutes, washed three times in sterile distilled water. The sterilized infected partitions were cut into $5 \times 5 \mathrm{~mm}$ smaller fragments and directly placed on petri plates containing Potato Dextrose Agar (PDA, Hi-media, India) supplemented with $100 \mathrm{mg} / \mathrm{L}$ streptomycin sulphate and then incubated at $25 \pm 2^{\circ} \mathrm{C}$ for $5-7$ days under $12 \mathrm{~h}$ light and dark conditions. The hyphal tips from each developing colony's margin were sub-cultured and maintained on PDA, with a sterile finely pointed needle and again incubated on $25 \pm 2^{\circ} \mathrm{C}$ for $5-7$ days.

\section{Micro-microscopic observations and identification}

The isolated fungal culture was observed under an Olympus SZX2 stereomicroscope. Cultural and microscopic features were studied on PDA culture media. Colony morphology including colour, shape, and growth rate was determined after 7 days of incubation on PDA at $25^{\circ} \mathrm{C}$ in darkness.

Morphological descriptions were based on slide preparations mounted in lactophenol-cotton blue mount mixture from pure cultured fungus on PDA isolated from infected area of leaves. The detailed observations of morphological characters were carried out at different magnification through Leica DM 2000 LED light microscope $(200 \times$ and $400 \times)$ and the microscopic structures were measured (shape, colour, and cell number), size (length and width). The microphotographs of the fungus were taken and stored in electronic format JPEG format. After detail study, the fungal culture was preserved in $10 \%$ glycerol and silica-gel and kept in KFRI-Microbial Culture collection at $4^{\circ} \mathrm{C}$ (Dhingra \& Sinclair 1995). The morphological identification of isolated pathogen was based on Ellis (1971, 1976), Barnett \& Hunter (1998), Seifert et al. (2011), Voglmayr \& Jaklitsch (2017), Mycobank (2020), Index Fungorum (2020) and Farr \& Rossman (2020).

\section{Pathogenicity test}

Pathogenicity test was evaluated on healthy leaves of Woodfordia fruticosa using universal protocol (Koch's postulates) by detached leaf method. The pathogenicity test was performed by inoculating seven millimeter mycelial disc of actively growing pathogen to the healthy leaves. The inoculated leaves were maintained at $25 \pm 2^{\circ} \mathrm{C}$ for five days while the control leaf was kept without mycelial disc sterilized with distilled water. After 5 days of observation, the similar disease symptoms appeared in experimentally kept leaf while the control leaf was symptomless (Fig. 3). The fungus $(C$. cassiicola) was re-isolated from experimentally diseased symptoms and grown again on PDA and obtained the same culture characteristics that are exactly similar to the mother culture. The slide was also prepared and observed under the microscope and found the pathogen 
similar to the previous one, which proved the pathogenicity of the isolated pathogen. The experiment was performed in triplicate.
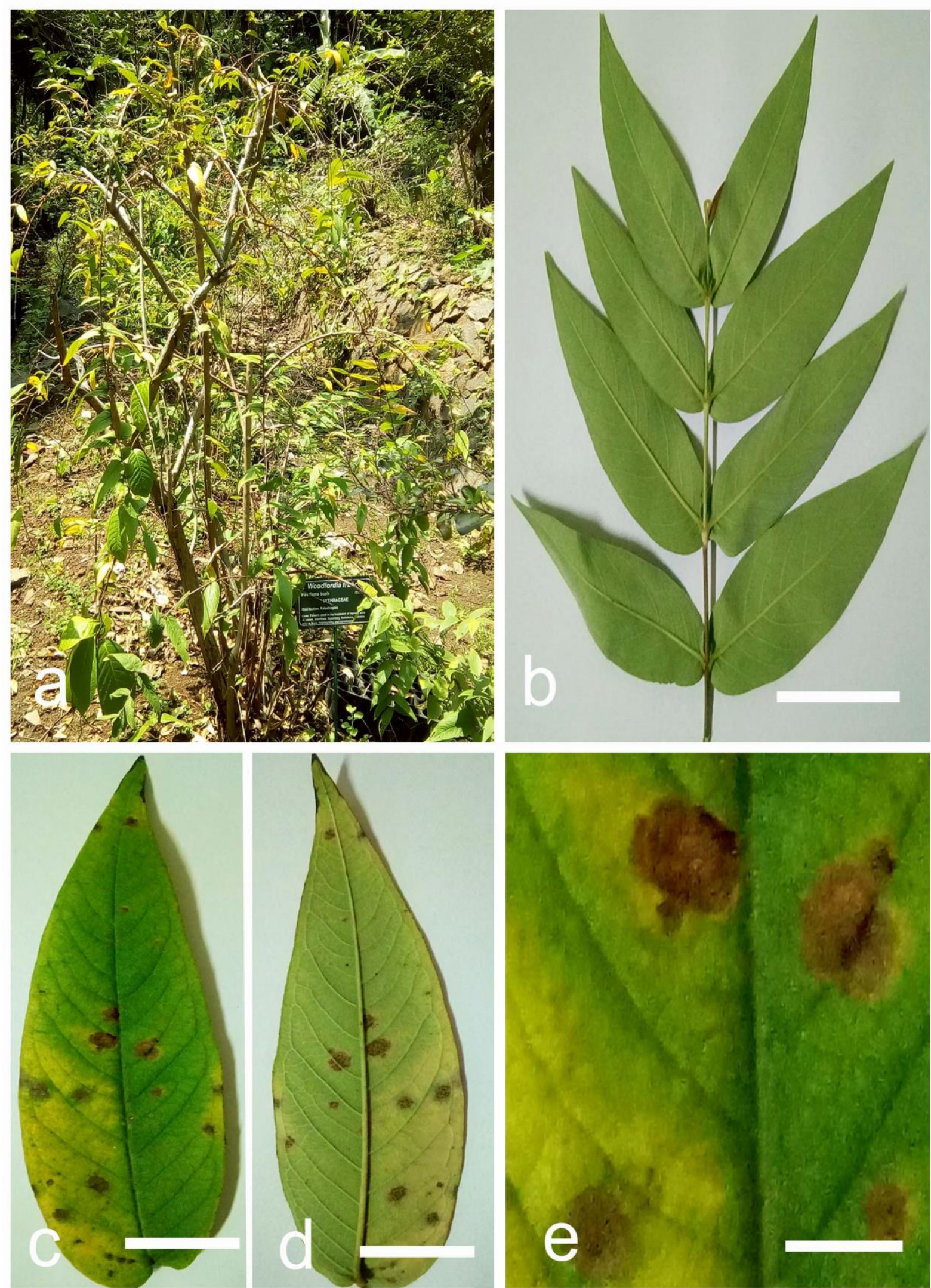

Fig. 1 - Woodfordia fruticose. a Infected plant in habitat. b Healthy leaves. c Upper surface (adaxial) of infected leaf. d Lower surface (abaxial) infected leaf. e Symptoms enlarge view. Scale bar $=20 \mathrm{~mm}$. 

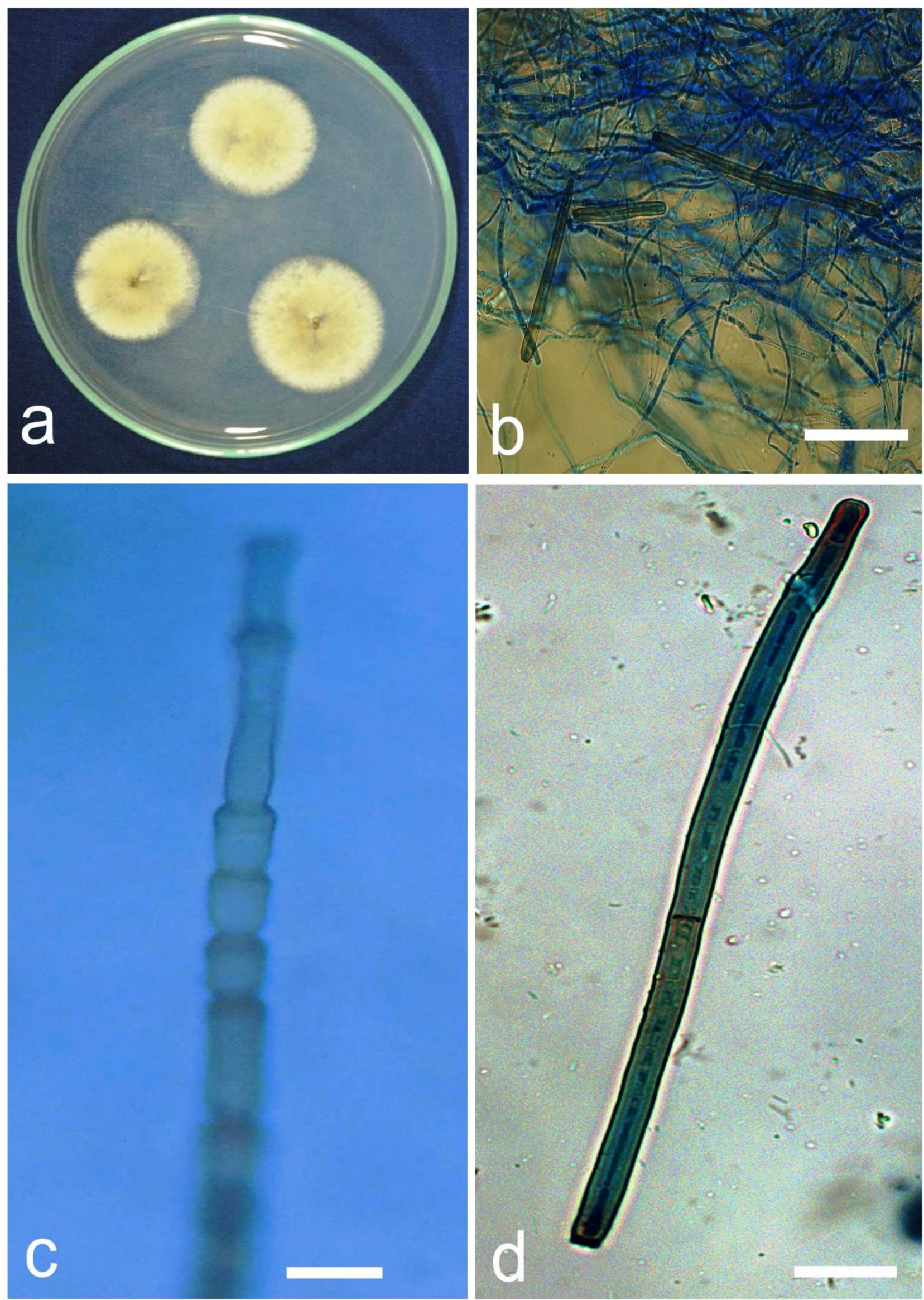

Fig. 2 - Corynespora cassiicola (Berk. \& Curtis) C.T. Wei. a Pure culture. b Mycelium and conidia. c Conidiophore. $d$ Single conidium. Scale bar: $b=50 \mu \mathrm{m}, \mathrm{c}-\mathrm{d}=20 \mu \mathrm{m}$. 

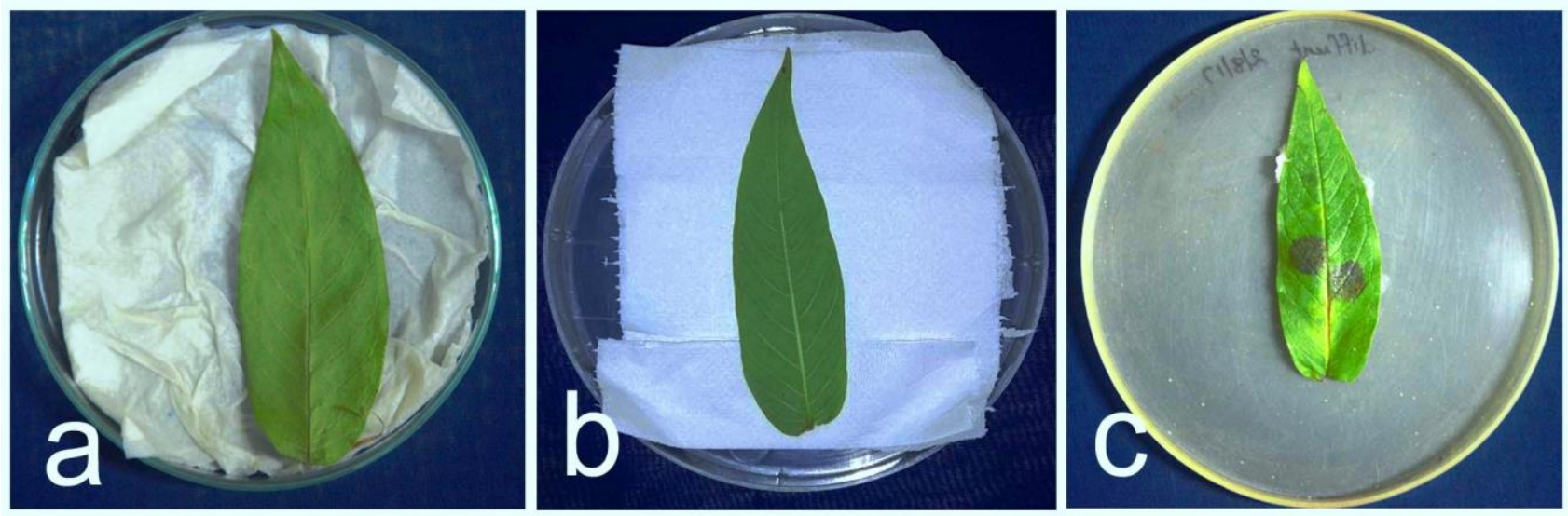

Fig. 3 - Pathogenicity test of isolated fungus (C. cassiicola) on Woodfordia fruticosa leaf. a, b Upper and lower surface of control leaf sprayed with distilled water. c Leaf with $7 \mathrm{~mm}$ fungal mycelial disc after 5 days.

\section{Results}

Infected leaf sample of $W$. fruticosa was collected from KFRI Medicinal Plants Garden, Peechi. The disease bearing leaves (infected leaves) were cut into smaller size $(5 \times 5 \mathrm{~mm})$ and then sterilized in sodium hypochlorite ( $2 \mathrm{~min}$.). After this, they were washed with sterile distilled water, plated on PDA media, and incubated at $25 \pm{ }^{\circ} \mathrm{C}$ for 5-7 days under a $12 \mathrm{~h}$ light and dark condition. The isolated fungus colony was observed under stereomicroscope. The slides were prepared from colony grown on PDA in lactophenol cotton blue mount mixture.

Observation under microscope, the fungus had shown following characteristics: Infection spots hypogenous i.e. on the lower surface, circular to sub circular 2-10 mm (Fig. 1). Sexual morph: Undetermined. Asexual morph: Colonies hypophyllous, effuse, brown. Mycelium branched, septate, sub hyaline. Stromata absent. Colony on PDA whitish to brownish, Conidiophores present, mononematous, straight to somewhat flexuous, smooth, thick walled, base swollen, apex truncate, over nine proliferated septa, 91.2-185.3 $\mu \mathrm{m}-5.5-6.7 \mu \mathrm{m}$, hila unthickend. Conidia simple, acropleurogenous, solitary, dry, obclavate to obclavatocylindrical, 4-15 transversely septate, smooth, thick walled, brown, base flat to obtuse, $91.2-185.3 \mu \mathrm{m}-5.5-6.7 \mu \mathrm{m}(\mathrm{n}$ =10), hila unthickend but darkened (Fig. 2).

Based on morphological characteristics and pathogenicity, the pathogen was identified as $C$. cassiicola (Berk. \& Curt.) C.T. Wei, is a significant and an ubiquitous mycopathogen belongs to Corynesporascaceae reported globally known to cause leaf spot and other diseases over 530 species of plants in 53 families (Dixon et al. 2009). Literature survey indicated no record of $C$. cassiicola on this host from India and Kerala (Bilgrami et al. 1991, Jamaluddin et al. 2004, Florence 2004, Farr \& Rossman 2020). Corynespora woodfordiana Meenu et al. (1997) and C. woodfordae Verma et al. (2008) have been previously reported from Nepal and Central India, respectively. To the best of my knowledge and as per survey of literature, this is the first report of C. cassiicola causing leaf spots on Woodfordia fruticosa. The plant ( $W$. fruticosa) provides a significant medicinal value, and present finding will help to plan effective disease management.

\section{Acknowledgements}

We would like to thanks the Director, KSCSTE-Kerala Forest Research Institute, Peechi for providing necessary facility. Thankfulness is also due to Curator, AMH-ARI, Pune for providing accession number of the specimen. We are also grateful to anonymous reviewers for their useful suggestion and remarks on manuscript. One of the authors (SK) would like to thanks DBT, Govt. of India for financial support (BT/PR29521/FCB/125/15/2018). 


\section{References}

Ahuja BS. 1965 - Medicinal Plants of Saharanpur. Gurukul Kangri Printing Press, Hardwar, India. Barnett HL, Hunter BB. 1998 - Illustrated Genera of Imperfect Fungi. 4th Edition, APS Press, St. Paul, $218 \mathrm{p}$.

Bilgrami KS, Jamaluddin, Rizwi MA. 1991 - Fungi of India: List and references. Today's and Tomorrow's Printers and Publishers, New Delhi. 798p.

Castañeda-Ruiz RF. 2005 - Metodologíaen el estudio de loshongosanamorfos. 182-183. Anais doV Congresso Latino Americano de Micología.

Chopra RN, Nayar SL, Chopra IC. 1956 - Glossary of Indian Medicinal Plants. CSIR, Delhi, India. Dhingra OB, Sinclair JB. 1995 - Basic Plant Pathology Methods. 2nd Edition, CRC Press, Boca Raton.

Dixon LJ, Schlub RL, Pernezny K, Datnoff LE. 2009 - Host specialization and phylogenetic diversity of Corynespora cassiicola. Phytopathology 99(9), 1015-1027.

Dutt UC. 1922 - The Materia Medica of the Hindus. Adi Ayurveda Machine Press, Kolkata, India.

Ellis MB. 1971 - Dematiaceous Hyphomycetes, CMI, Kew, England.

Ellis MB. 1976 - More Dematiaceous Hyphomycetes, CMI, Kew, England.

Farr DF, Rossman AY. 2020 - Fungal Databases, U.S. National Fungus Collections, ARS, USDA. https://nt.ars-grin.gov/fungaldatabases/ (Retrieved September 5, 2020)

Florence MEJ. 2004 - Biodiversity and Documentation for Kerala Part 2: Microorganisms (Fungi).Kerala Forest Research Institute, Peechi, Kerala. 293p.

Hawksworth DL. 1974 - Mycologist's Handbook. CMI, Kew.

Index Fungorum. 2020 - http://www.indexfungorum.org/ (Accessed September 5, 2020)

Jamaluddin, Goswami MG, Ojha BM. 2004 - Fungi of India 1989-2001. Scientific Publishers, Jodhpur, Rajasthan, India. 326 p.

Meenu, Singh A, Singh SK. 1997 - Some new species of Corynespora. Indian Phytopathology $50(1), 17-24$.

MycoBank. 2020 - https://www.mycobank.org/ (Fungal databases nomenclature and species banks). (Accessed September 5, 2020)

Nadkarni KM. 1954 - Indian MateriaMedica, Popular Book Depot, Mumbai, India. 3(2), 489.

Oudhia P. 2003 - Interaction with the Herb Collectors of Gandai Region, Chhatisgarh, MP, India.

Sasidharan N. 2012 - Flowering plants of Kerala V2. Kerala Forest Research Institute, Peechi, Kerala.

Seifert K, Morgan-Jones G, Gams W, Kendrick B. 2011 - The Genera of Hyphomycetes. CBS Biodiversity Series no. 9: 1-997. CBS-KNAW Fungal Biodiversity Centre, Utrecht, Netherlands.

Sharma PV. 1956 - Dravyagun Vigyan. The Chowkhamba, Varanasi.

Voglmayr H, Jaklitsch WM. 2017 - Corynespora, Exosporium and Helminthosporium revisited New species and generic reclassification. Studies in Mycology 87, 43-76.

Verma RK, Sharma N, Soni KK, Jammaluddin. 2008 - Forest Fungi of Central India. International Book Distributing Co. Lucknow. 418p. 